\title{
Liter per Nanomole per Day
}

National Cancer Institute

\section{Source}

National Cancer Institute. Liter per Nanomole per Day. NCI Thesaurus. Code C85689.

Liters per nanomole per day. 